\title{
Proton Conductivity of Ni, Y Co-Doped $\mathrm{BaZrO}_{3}$
}

\author{
Hiroya Morishita1, Yumiko Ikebe ${ }^{2}$, Eriko Ban ${ }^{2 *}$ \\ ${ }^{1}$ Department of Materials Science and Engineering, Meijo University, Nagoya, Japan \\ ${ }^{2}$ Department of Applied Chemistry, Meijo University, Nagoya, Japan \\ Email: ^ban@meijo-u.ac.jp
}

How to cite this paper: Morishita, H., Ikebe, Y. and Ban, E. (2018) Proton Conductivity of Ni, Y Co-Doped $\mathrm{BaZrO}_{3}$. Journal of Materials Science and Chemical Engineering, 6, 19-27.

https://doi.org/10.4236/msce.2018.66002

Received: May 21, 2018

Accepted: June 23, 2018

Published: June 26, 2018

Copyright $\odot 2018$ by authors and Scientific Research Publishing Inc. This work is licensed under the Creative Commons Attribution International License (CC BY 4.0).

http://creativecommons.org/licenses/by/4.0/ (c) (i) Open Access

\begin{abstract}
Dense sintered bodies of proton conducting $\mathrm{BaZrO}_{3}$ (BZ) and Y-doped $\mathrm{BaZrO}_{3}(\mathrm{BZ}-\mathrm{Y})$ were obtained at $1600^{\circ} \mathrm{C}$ for a short sintering time of 5 hours, by the addition of $\mathrm{NiO}$ as a sintering promotion agent. The relative density and grain growth of samples, Ni-doped $\mathrm{BaZrO}_{3}(\mathrm{BZ}-\mathrm{N})$ and $\mathrm{Ni}, \mathrm{Y}$ co-doped $\mathrm{BaZrO}_{3}$ (BZ-NY), were increased with increasing Ni addition. The sinterability of BZ-NY was greatly improved just to add only $0.6 \mathrm{~mol} \% \mathrm{Ni}$ and the relative density of this sample was more than $98 \%$, in contrast to that of $60 \%$ at most for BZ-Y without Ni addition. Electrical conductivity of BZ-NY added Ni $1.0 \mathrm{~mol} \%, \mathrm{BaZr}_{0.91} \mathrm{Ni}_{0.01} \mathrm{Y}_{0.08} \mathrm{O}_{3-\alpha}$, was more than $10^{-3} \mathrm{~S} \cdot \mathrm{cm}^{-2}$ at $900^{\circ} \mathrm{C}$ in a wet $1 \%$ hydrogen atmosphere, which value was 10 times higher than that of BZ-Y. In addition, the kind of electrical conduction carrier and an ionic transport number were also examined by employing various concentration cells. It was found that the proton conduction was dominant for both BZ-N and BZ-NY samples, although BZ-NY showed scarcely oxygen-ion conduction approximately $10 \%$ in a high temperature range higher than $800^{\circ} \mathrm{C}$. From these results, as mall amount of $\mathrm{Ni}$ addition found to be effective for improvement of both the sinterability and the electrical conductivity.
\end{abstract}

\section{Keywords}

Proton Conducting Oxide, Barium Zirconate, Ni, Y Co-Doping, Electrical Conductivity, Ionic Transport Number

\section{Introduction}

The electrochemical device employing proton conducting perovskite-type oxide has a great potential for practical applications, such as a large scale fuel cell and hydrogen sensor etc. [1]. Among these proton conducting ceramics, barium cerate $\left(\mathrm{BaCeO}_{3} ; \mathrm{BC}\right)$ and barium zirconate $\left(\mathrm{BaZrO}_{3} ; \mathrm{BZ}\right)$ are the well-known materials [1] [2]. BZO partially substituted by low valence cations has been paid great 
attention to because of the superior mechanical strength and good chemical stability [3] [4]. However, the BZ doped with additive is very difficult to sinter, that is, high temperature more than $1700^{\circ} \mathrm{C}$ is necessary to obtain a high-density sample. BZ sample without sintering additives shows low conductivity for grain-boundary resistivity even though a long time heat treatment at high temperature was carried out [1] [5] [6] [7]. In order to overcome these problems, it has been recognized that addition of small amount of transition metal $(\mathrm{Co}, \mathrm{Ni}$, $\mathrm{Cu}, \mathrm{Zn}$, etc.) as a sintering promotion agent is effective on improvement of sinterability [8] [9] [10] [11] [12]. Because Ni is used for the anode electrode material of a fuel cell [13] [14], further consideration is required to obtain the high performance fuel cell using BZ and BZ-Y electrolyte. Therefore, in other word, it is connected for elucidation of the influence of interfacial reaction between the electrolyte and the electrode, diffusion of $\mathrm{Ni}$ and the coefficient of thermal expansion. It is also very important for the fundamental research and application to understand the roll of $\mathrm{Ni}$ additive mechanism.

In this study, the sinterability and the electrical properties of $\mathrm{BaZr}_{1-\mathrm{x}}(\mathrm{Ni}$, $\mathrm{Y})_{\mathrm{x}} \mathrm{O}_{3-\alpha}$ co-doped with mixture of $\mathrm{Ni}$ and $\mathrm{Y}$ are investigated. Their proton conductivities are also examined.

\section{Experimental Procedure}

The powder for bulk samples was synthesized by an ordinary solid state reaction method. Two kinds of sample with $\mathrm{NiO}$ additive representing the chemical formula of $\mathrm{BaZr}_{1-\alpha} \mathrm{Ni}_{a} \mathrm{O}_{3-\alpha}(\mathrm{BZ}-\mathrm{N})$ and $\mathrm{BaZr}_{0.92-\mathrm{b}} \mathrm{Ni}_{\mathrm{b}} \mathrm{Y}_{0.08} \mathrm{O}_{3-\alpha}(\mathrm{BZ}-\mathrm{NY})$ were prepared by using commercially available $\mathrm{BaCO}_{3}, \mathrm{ZrO}_{2}, \mathrm{Y}_{2} \mathrm{O}_{3}$ and $\mathrm{NiO}$ as starting reagents. These reagents were mixed with an organic solvent by using a planetary-motion ball-milling machine. After drying at $60^{\circ} \mathrm{C}$ for $30 \mathrm{~min}$, the mixed powders were calcined at $1200^{\circ} \mathrm{C}$ for $5 \mathrm{~h}$ in air. Two times of ball-milling operation was repeated to make the size of the particle smaller. By using the uniaxial pressing and cold isostatic pressing (CIP), thus prepared calcined powders were molded into a pellet of $20 \mathrm{~mm}$ in diameter by adding molding pressure of 200 $\mathrm{MPa}$ for $2 \mathrm{~min}$. The green pellets were sintered at $1600^{\circ} \mathrm{C}$ for $5 \mathrm{~h}$ in air at a heating rate of $200^{\circ} \mathrm{C} / \mathrm{h}$ from room temperature to $1300^{\circ} \mathrm{C}$ and $50^{\circ} \mathrm{C} / \mathrm{h}$ to $1600^{\circ} \mathrm{C} / \mathrm{h}$ and cooling rate of $50^{\circ} \mathrm{C} / \mathrm{h}$ from $1600^{\circ} \mathrm{C}$ to $1400^{\circ} \mathrm{C} / \mathrm{h}$ and $200^{\circ} \mathrm{C} / \mathrm{h}$ to room temperature. Differential thermal analysis (DTA), differential scanning calorimetry (DSC) and thermomechanical analysis (TMA) was used to study transition and melting behavior of samples at a heating and cooling rate of $10^{\circ} \mathrm{C} / \mathrm{min}$.

After heat treatment, the crystal structure of sample was analyzed using X-ray diffractometer (XRD). The microstructural observation and the chemical composition were examined by a scanning electron microscope (SEM) and an energy dispersive X-ray analyser (EDXA). The relative density measurement by the Archimedes method was performed as evaluation of sinterability. For the measurements of electrical properties, porous platinum mesh was attached on both 
sides of pellet using Pt paste as electrodes. Electrical conductivities were measured at temperature range of $500^{\circ} \mathrm{C}-900^{\circ} \mathrm{C}$ in wet $1 \% \mathrm{H}_{2}+\mathrm{Ar}$ atmosphere by complex impedance method. Furthermore, in order to investigate the proton contribution to conduction, an electromotive force (EMF) was also measured at temperature range of $500^{\circ} \mathrm{C}-900^{\circ} \mathrm{C}$ by using some kind of gas concentration cell, such as a hydrogen gas concertation cell and a water vapor concentration cell.

\section{Results and Discussion}

\subsection{Sinterability and Microstructure}

After sintering, we examined the crystal phases of the samples by XRD analysis. The diffraction patterns indicated that all samples doped with Ni lower than 0.05 mol showed highly crystalline $\mathrm{BaZrO}_{3}$ phase, but the reflection peaks of secondary $\mathrm{NiO}$ phase were also detected in samples which added $\mathrm{Ni}$ more than amolar ratio of 0.05. From SEM observation and EDX analysis, $\mathrm{NiO}$ precipitates and the related Ni-rich regions were confirmed on surface of these samples. Therefore, samples less than $\mathrm{Ni}$ adding $1.0 \mathrm{~mol} \%$ are subsequently investigated.

Figure 1 shows the relationships between the relative density of BZ-N and $\mathrm{BZ}-\mathrm{NY}$ and $\mathrm{Ni}$ contents. Both samples sintered at $1600^{\circ} \mathrm{C}$ for $5 \mathrm{~h}$ exhibit the tendency that the relative density of samples increases with increasing Ni-doping level. The relative density of BZ-NY doped with Ni higher than a molar ratio of 0.006 remarkably improves, contrast to that of BZ-NY without $\mathrm{Ni}$ is $60 \%$ at most. BZ-NY samples doped with Ni higher than a molar ratio of 0.008 showed the relative density exceed $99 \%$. The Ni addition higher than a molar ratio of 0.006 is found to be effective to obtain a high-density sintered body for BZ-N and BZ-NY.

In the case of BZ-NY heat-treated at rather low temperature, the BZ-NY with Ni 0.006 mol showed dense structure even when at low sintering temperature around $1300^{\circ} \mathrm{C}$. Thermal analysis using TG and DSC was performed to investigate the thermal behaviour. The powdery sample was $\mathrm{BaCO}_{3}$ and $\mathrm{NiO}$ which were mixed by the molar ratio of 1:1. TG and DSC profiles are shown in Figure 2. TG curve exhibits weight loss of $15.6 \%$ which is shown at temperature range from $800^{\circ} \mathrm{C}$ to around $950^{\circ} \mathrm{C}$ due to decomposition of $\mathrm{BaCO}_{3}$. The other hands, DSC signal reveals some thermal events, the main of which, at around $1130^{\circ} \mathrm{C}$, is distinct endothermic peak. It is thought that this temperature corresponds to the partial melting by a reaction between $\mathrm{Ba}$ and Ni.In spite of the fact that both the volume shrinkage and a melting feature were confirmed in the sample which sintered at $1200^{\circ} \mathrm{C}$, these features could not be seen in the $1100^{\circ} \mathrm{C}$ heat-treated sample. It is assumed that a generation of a reaction product such as $\mathrm{BaNiO}_{\mathrm{x}}$ proceeds continually at higher temperature. The consequence means that the change of solid phase reaction to liquid phase reaction occurred at even low temperature range of between $1100^{\circ} \mathrm{C}$ and $1200^{\circ} \mathrm{C}$ by a $\mathrm{Ni}$ addition, and then dense structure was formed. 


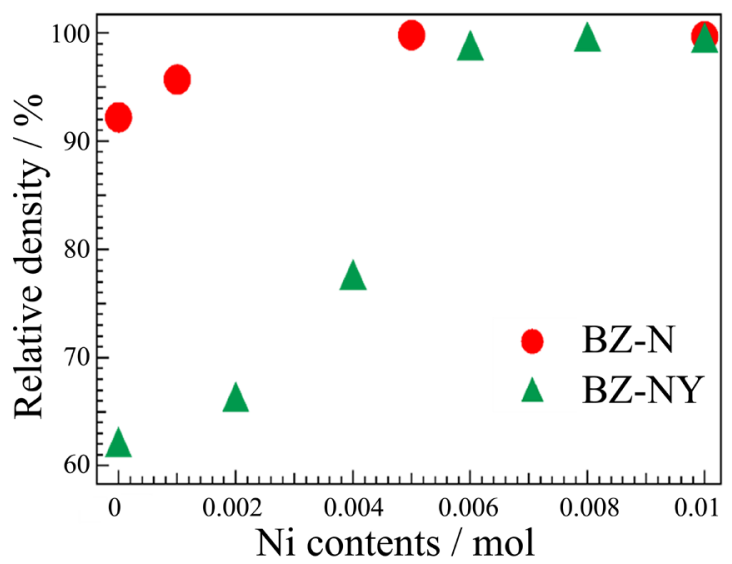

Figure 1. Relative density of BZ-N and BZ-NY pellets sintered at $1600^{\circ} \mathrm{C}$ for $5 \mathrm{~h}$.

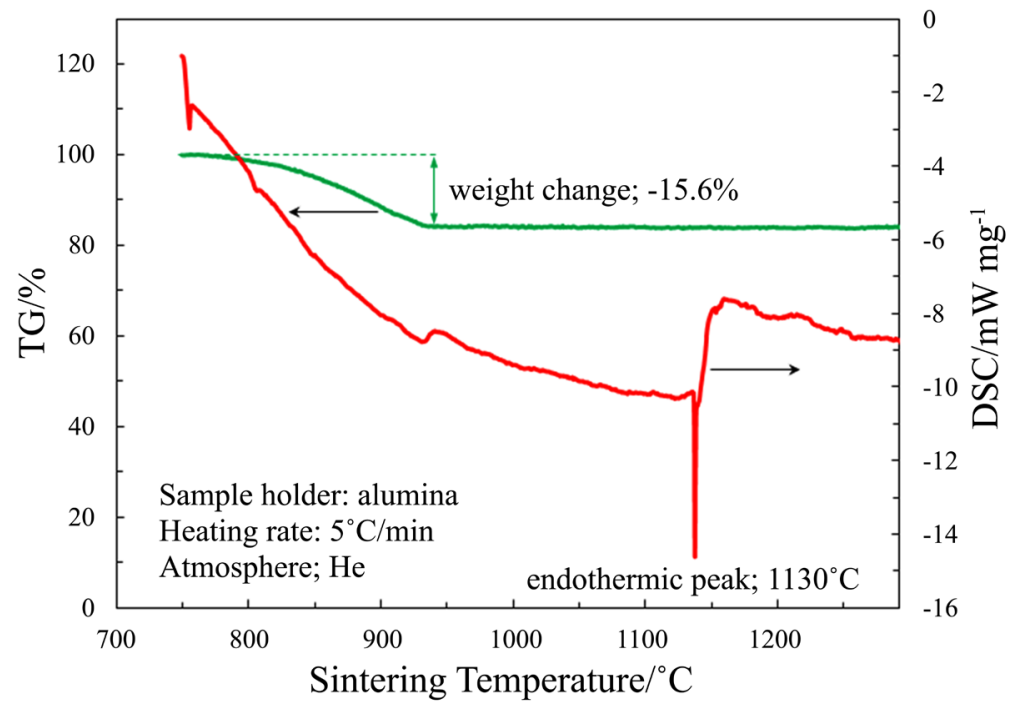

Figure 2. TG and DSC profiles for a mixed powder of $\mathrm{BaCO}_{3}$ and $\mathrm{NiO}$.

Figure 3 shows the typical microstructure of fracture surface for BZ-N and BZ-NY. In the case of BZ-N shown in upper row, the microstructure drastically changes by $\mathrm{Ni}$ addition even though the small amount of $\mathrm{Ni}$. Although $\mathrm{Ni}$-free sample shows the microstructure constructed with smaller grains less than $1 \mu \mathrm{m}$, the crystal grain grown is obviously promoted in the Ni-doped samples. Similar consequence is reported in other works, which shows that small grain size and the densification of Y-doped BZO treated in an ordinary sintering condition [15]. It seems that the sintering is accelerated due to producing the partially melted liquid phase because melt point is below $1600^{\circ} \mathrm{C}$ for composition of $\mathrm{Ba}$ and $\mathrm{Ni}$. In Ref. [16], it has been reported that $\mathrm{NiO}$ helps reducing sintering time and temperature which mitigates the extent of unwanted reactions. Bozza et al. have reported that $\mathrm{Ni}$ inclusion strongly enhanced densification and grain growth process [12]. Our experimental result on the sinterability shows a similar tendency and accords with other reports.

Although we did not show it in the figure, the following experimental result 

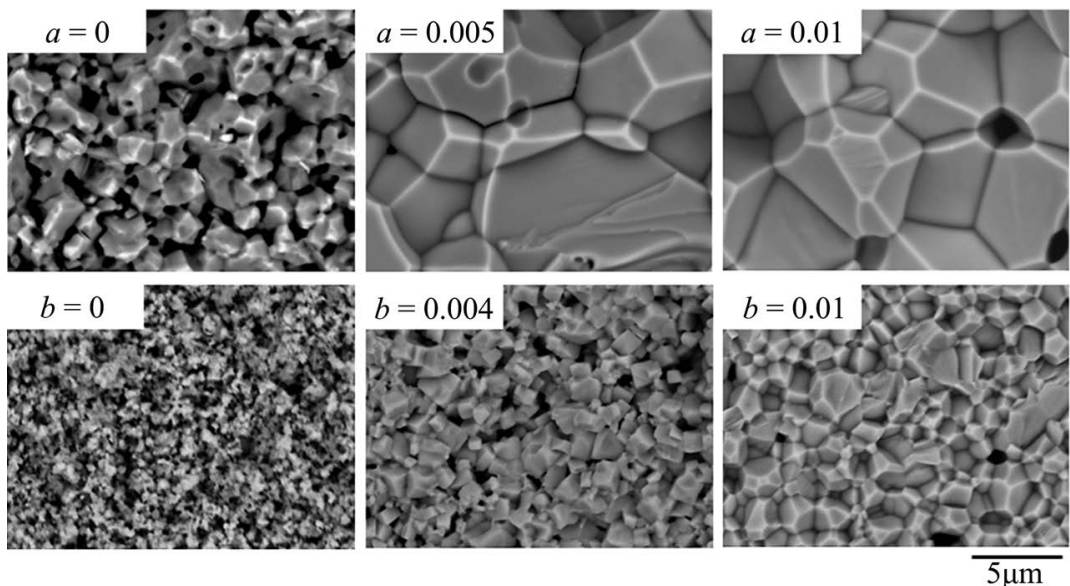

Figure 3. SEM images of the fracture surface for pellets sintered at $1600^{\circ} \mathrm{C}$ for $5 \mathrm{~h}$. Upper row: $\mathrm{BaZr}_{1-\mathrm{a}} \mathrm{Ni}_{\mathrm{a}} \mathrm{O}_{3-\alpha}\left(\mathrm{a}=0,0.005\right.$ and 0.01), Lower row: $\mathrm{BaZr}_{0.92-\mathrm{b}} \mathrm{Ni}_{\mathrm{b}} \mathrm{Y}_{0.08} \mathrm{O}_{3-\alpha}(\mathrm{b}=0,0.004$ and 0.01).

about dispersibility and solid solubility limit of $\mathrm{Ni}$ was also acquired. SEM observation showed that $\mathrm{NiO}$ particles were dispersed in the grain boundary for BZ-N when the Ni doping level was higher than a molar ratio of 0.01 . Furthermore, due to the detection of impurities phases of XRD analysis for this sample, we derived that the solubility limit of $\mathrm{Ni}$ to $\mathrm{BZ}$ sample was under $0.01 \mathrm{~mol}$. Same results have been reported that a small amount of $\mathrm{Ni}$ addition around $0.004 \mathrm{~mol}$ into $\mathrm{BaCe}_{0.9} \mathrm{Y}_{0.1} \mathrm{O}_{3-\alpha}$ is effective on the improvement of sinterability [10].

\subsection{Electrical Properties}

Effect of Ni addition on the electrical conductivity of BZ-N and BZ-NY was investigated. Figure 4 shows the total conductivities formed Arrhenius plot for BZ-N and BZ-NY samples measured in wet $1 \% \mathrm{H}_{2}+$ Ar atmosphere. Both sample showed the increased the conductivity with increasing Ni doping concentration and measurement temperature. Although grain size of BZ-NY samples are smaller than one of BZ-N samples as shown in Figure 3, the conductivities of BZ-NY samples are high. In addition, we confirmed in calculation that the activation energy of this sample is small. Similar consequence, the improvement of the conductivity for BZO by Y doping, has reported [17]. In this present work, the total conductivities of these samples increase with increasing Ni-doping level when the $\mathrm{Y}$ and $\mathrm{Ni}$ were co-doped. It seems that the grain boundary resistance of these samples tends to reduce with the increase in $\mathrm{Ni}$ content from Cole-Cole plot by complex impedance measurement. Because the grain-boundary resistivity is known to adversely affect electric conductivity of BZO [4] [7], therefore we assume that improvement of sinterability by $\mathrm{Ni}$-doping leads to the enhancement of conductivity.

These solid electrolytes under wet hydrogen atmosphere have the possibility of candidate of the electrical conducting carrier that $\mathrm{H}^{+}, \mathrm{O}^{2-}, \mathrm{h}^{+}, \mathrm{e}^{-}$and metal cations of the constituent elements, such as $\mathrm{Ba}^{2+}, \mathrm{Zr}^{4+}, \mathrm{Y}^{3+}$ and $\mathrm{Ni}^{2+}$ contribute to conduction. 


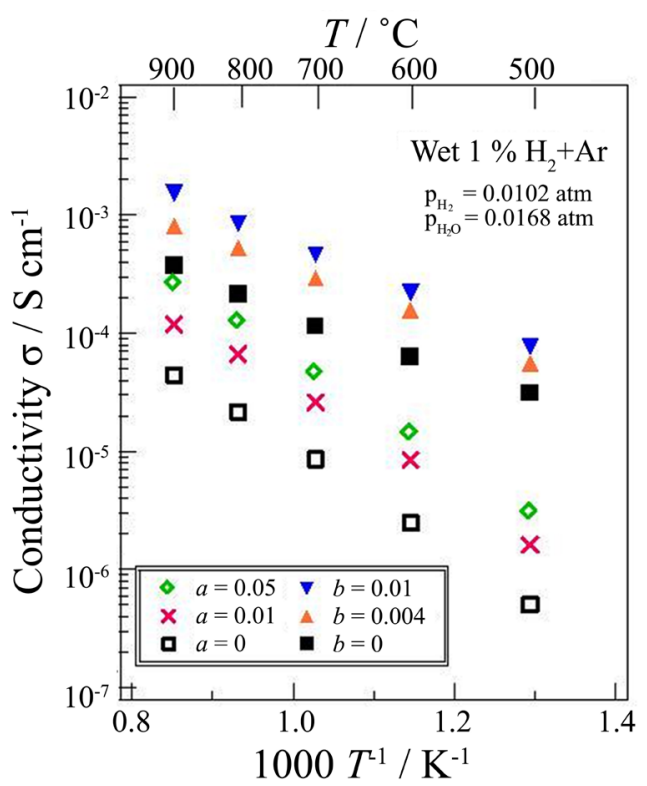

Figure 4. Arrhenius plots of total conductivities for the $\mathrm{BaZr}_{1-\mathrm{a}} \mathrm{Ni}_{\mathrm{a}} \mathrm{O}_{3-\alpha}$ and $\mathrm{BaZr}_{0.92-\mathrm{b}} \mathrm{Ni}_{\mathrm{b}} \mathrm{Y}_{0.08} \mathrm{O}_{3-\alpha}$.

To investigate what kind of electrical conductive species affects electrical conductivity, we measured EMF of hydrogen concentration cell. Figure 5 shows EMF of hydrogen concentration cell by using $\mathrm{BaZr}_{0.99} \mathrm{Ni}_{0.01} \mathrm{O}_{3-\alpha}$ and $\mathrm{BaZr}_{0.912} \mathrm{Ni}_{0.008} \mathrm{Y}_{0.08} \mathrm{O}_{3-\alpha .}$. The theoretical electromotive force is shown in the figure with a broken line. Both samples obtain EMF of equivalent to the theoretical value calculated from Nernst's equation at from 500 to $900^{\circ} \mathrm{C}$. This indicates that ion (proton and oxygen ion) is major conductive species. Therefore, we consider that there is little conduction with $\mathrm{h}^{+}$and $\mathrm{e}^{-}$in both samples.

To estimate proton conduction regarding ion conduction in samples, we calculated oxygen ion transport number $\left(t_{0}\right)$ by measuring EMF of water vapour concentration cell. Proton transport number $\left(t_{\mathrm{p}}\right)$ in samples is obtained from the formula (1) shown below.

$$
t_{\mathrm{p}}=100-t_{\mathrm{o}}
$$

Figure 6 shows relationships between proton transport number and operating temperature for $\mathrm{BaZr}_{0.99} \mathrm{Ni}_{0.01} \mathrm{O}_{3-\alpha}$ and $\mathrm{BaZr}_{0.912} \mathrm{Ni}_{0.008} \mathrm{Y}_{0.08} \mathrm{O}_{3-\alpha}$ pellets. For comparison, the proton transport number of $\mathrm{BaCe}_{0.95} \mathrm{Y}_{0.05} \mathrm{O}_{3-\alpha}$ measured in same condition are also shown with explanatory note of the black circle. BZ-N samples have over $95 \%$ of proton transport number regardless of operating temperature. Proton transport number of BZ-NY samples is the same as BZ-N samples. When operating temperature exceeds $700^{\circ} \mathrm{C}$, proton transport number of BZ-NY samples reduces and samples have a little contribution of oxygen ion conduction. The contribution of the oxygen ion transference number of these BZ-N and BZ-NY samples is small whereas the ratio of oxygen ion transference number for $\mathrm{BaCe}_{0.95} \mathrm{Y}_{0.05} \mathrm{O}_{3-\alpha}$ is increased up to $27 \%$ with increasing the temperature. It was confirmed that the proton conduction is dominant for the BZ-N and BZ-NY. 


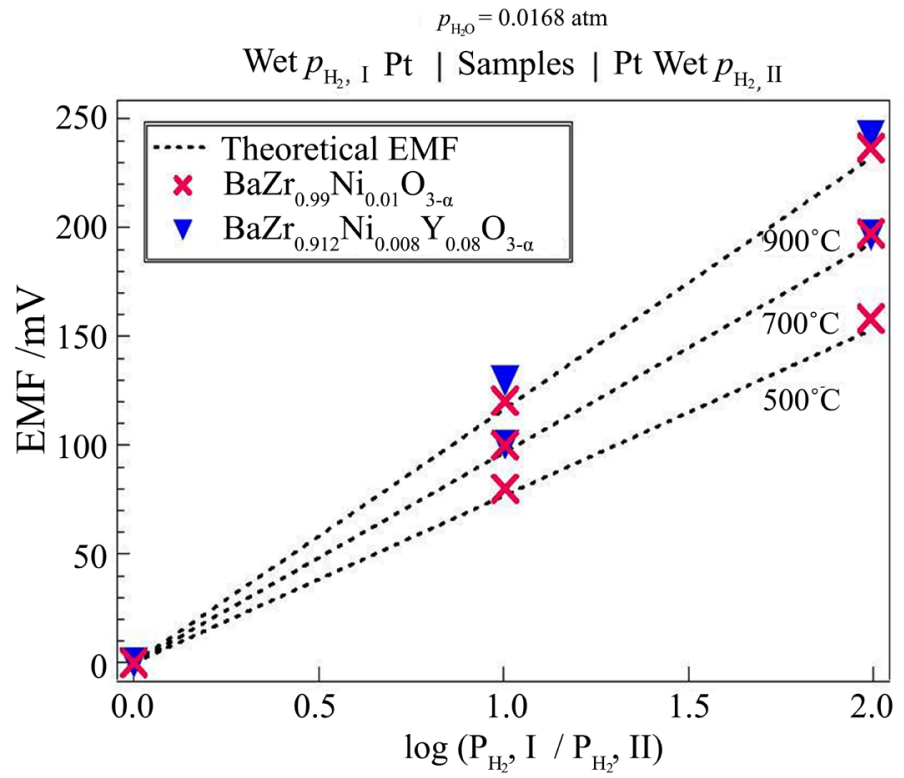

Figure 5. EMF of the hydrogen concentration cell for $\mathrm{BaZr}_{0.99} \mathrm{Ni}_{0.01} \mathrm{O}_{3-\alpha}$ and $\mathrm{BaZr}_{0.912} \mathrm{Ni}_{0.008} \mathrm{Y}_{0.08} \mathrm{O}_{3-\alpha}$. Theoretical EMF was shown by broken lines.

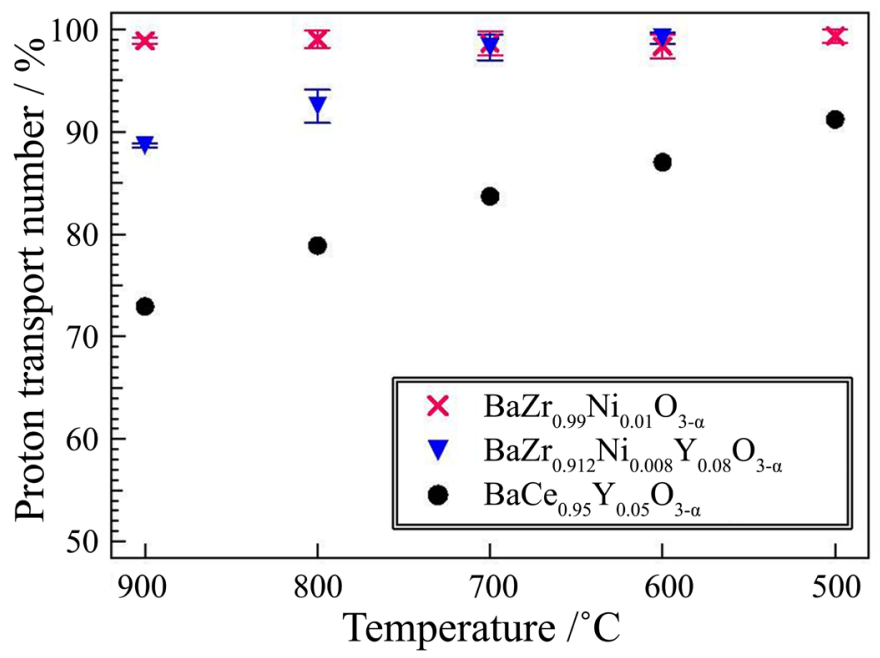

Figure 6. Proton transport number measured at various temperature by water vapour concentration cell for $\mathrm{BaZr}_{0.99} \mathrm{Ni}_{0.01} \mathrm{O}_{3-\alpha}$ and $\mathrm{BaZr}_{0.912} \mathrm{Ni}_{0.008} \mathrm{Y}_{0.08} \mathrm{O}_{3-\alpha}$

\section{Conclusions}

The relative density and grain growth of BZ-N and BZ-NY samples were increased with increasing $\mathrm{Ni}$ doping. $\mathrm{Ni}$ addition leaded both the decrease of the grain boundary resistance and high conductivity. The relative density hither than $99 \%$ was obtained in the samples with Ni-doping in amount of more than $0.008 \mathrm{~mol}$, even when the sample treated at $1600^{\circ} \mathrm{C}$ for rather short time sintering. On the other hand, $\mathrm{NiO}$ precipitation was observed in $\mathrm{BZ}-\mathrm{N}$ doped with $\mathrm{Ni}$ 0.01 molar ratio. The solid solubility limit of $\mathrm{Ni}$ is assumed to be lower than 0.01 molar ratio. 
The EMF of both BZ-N and BZ-NY samples accorded with the theoretical value regardless of measurement temperature, ion conduction of proton and oxygen ion is dominant to all that in wet hydrogen atmosphere. From the measurement result of hydrogen and water vapor concentration cell, BZ-N electrolyte indicates the proton transport number higher than $95 \%$. It is suggested that the proton conduction is dominant for both BZ-N and BZ-NY samples, though $\mathrm{BZ}-\mathrm{NY}$ has a few oxygen conduction at high temperature range higher than $800^{\circ} \mathrm{C}$.

\section{References}

[1] Iwahara, H. (1996) Proton Conducting Ceramics and Their Applications. Solid State Ionics, 86-88, 9-15. https://doi.org/10.1016/0167-2738(96)00087-2

[2] Katahira, K., Kohchi, Y., Shimura, T. and Iwahara, H. (2000) Protonic Conduction in $\mathrm{Zr}$-Substituted $\mathrm{BaCeO}_{3}$. Solid State Ionics, 138, 91-98. https://doi.org/10.1016/S0167-2738(00)00777-3

[3] Fabbri, E., D’Epifanio, A., Bartolomeo, E.D., Licoccia, S. and Traversa, E. (2008) Tailoring the Chemical Stability of $\mathrm{Ba}\left(\mathrm{Ce}_{0.8-x} \mathrm{Zr}_{x}\right) \mathrm{Y}_{0.2} \mathrm{O}_{3-\delta}$ Protonic Conductors for Intermediate Temperature Solid Oxide Fuel Cells (IT-SOFCs). Solid State Ionics, 179, 558-564. https://doi.org/10.1016/j.ssi.2008.04.002

[4] Haile, S.M., Staneff, G. and Ryu, K.H. (2001) Non-Stoichiometry, Grain Boundary Transport and Chemical Stability of Proton Conducting Perovskites. Journal of Materials Science, 36, 1149-1160. https://doi.org/10.1023/A:1004877708871

[5] Tong, J., Clark, D., Hoban, M. and O'Hayre, R. (2010) Cost-Effective Solid-State Reactive Sintering Method for High Conductivity Proton Conducting Yttrium-Doped Barium Zirconium Ceramics. Solid State Ionics, 181, 496-503. https://doi.org/10.1016/j.ssi.2010.02.008

[6] Ito, N., Matsumoto, H., Kawasaki, Y., Okada, S. and Ishihara, T. (2008) Introduction of In or $\mathrm{Ga}$ as Second Dopant to $\mathrm{BaZr}_{0.9} \mathrm{Y}_{0.1} \mathrm{O}_{3-\delta}$ to Achieve Better Sinterability. Solid State Ionics, 179, 324-329. https://doi.org/10.1016/j.ssi.2008.02.047

[7] Duval, S.B.C., Holtappels, P., Vogt, U.F., Pomjakushina, E., Conder, K., Stimming, U. and Graule, T. (2007) Electrical Conductivity of the Proton Conductor $\mathrm{BaZr}_{0.9} \mathrm{Y}_{0.1} \mathrm{O}_{3-\delta}$ Obtained by High Temperature Annealing. Solid State Ionics, 178, 1437-1441. https://doi.org/10.1016/j.ssi.2007.08.006

[8] Nikodemski, S., Tong, J. and O'Hayre, R. (2013) Solid-State Reactive Sintering Mechanism for Proton Conducting Ceramics. Solid State Ionics, 253, 201-210. https://doi.org/10.1016/j.ssi.2013.09.025

[9] Babilo, P. and Haile, S.M. (2005) Enhanced Sintering of Yttrium-Doped Barium Zirconate by Addition of ZnO. Journal of the American Ceramic Society, 88, 2362-2368. https://doi.org/10.1111/j.1551-2916.2005.00449.x

[10] Costa, R., Grunbaum, N., Berger, M.-H., Dessemond, L. and Thorel, A. (2009) On the Use of $\mathrm{NiO}$ as Sintering Additive for $\mathrm{BaCe}_{0.9} \mathrm{Y}_{0.1} \mathrm{O}_{3-\alpha}$. Solid State Ionics, 180, 891-895. https://doi.org/10.1016/j.ssi.2009.02.018

[11] Ricote, S. and Bonanos, N. (2010) Enhanced Sintering and Conductivity Study of Cobalt or Nickel Doped Solid Solution of Barium Cerate and Zirconate. Solid State Ionics, 181, 694-700. https://doi.org/10.1016/j.ssi.2010.04.007

[12] Bozza, F., Bator, K., Kubiak, W.W. and Graule, T. (2016) Effects of Ni Doping on the Sintering and Electrical Properties of $\mathrm{BaZr}_{0.8} \mathrm{Y}_{0.2} \mathrm{O}_{3-\delta}$ Proton Conducting Elec- 
trolyte Prepared by Flame Spray Synthesis. Journal of the European Ceramics Society, 36,101-107. https://doi.org/10.1016/j.jeurceramsoc.2015.09.010

[13] Karczewski, J., Bochentyn, B., Molin, S., Gazda, M., Jasinski, P. and Kusz, B. (2012) Solid Oxide Fuel Cells with Ni-Infiltrated Perovskite Anode. Solid State Ionics, 221, 11-14. https://doi.org/10.1016/j.ssi.2012.06.002

[14] Lee, C.H., Lee, C.H., lee, H.Y. and Oh, S.M. (1997) Microstructure and Anodic Properties of Ni/YSZ Cermets in Solid Oxide Fuel Cells. Solid State Ionics, 98, 39-48. https://doi.org/10.1016/S0167-2738(97)00100-8

[15] Babilo, P., Uda, T. and Haile, S.M. (2007) Processing of Yttrium-Doped Barium Zirconate for High Proton Conductivity. Journal of Materials Research, 22, 1322-1330. https://doi.org/10.1557/jmr.2007.0163

[16] Vahid Mohammadi, A. and Cheng, Z. (2015) Fundamentals of Synthesis, Sintering Issues, and Chemical Stability of $\mathrm{BaZr}_{0.1} \mathrm{Ce}_{0.7} \mathrm{Y}_{0.1} \mathrm{Yb}_{0.1} \mathrm{O}_{3-\delta}$ Proton Conducting Electrolyte for SOFCs. Journal of the Electrochemical Society, 162, F803-F811.

http://jes.ecsdl.org/content/162/8/F803.full?sid=9025e163-d25f-4c3f-bd6d-816d733f b248\#content-block https://doi.org/10.1149/2.0021508jes

[17] Iwahara, H., Yajima, T., Hibino, T., Ozaki, K. and Suzuki, H. (1993) Protonic Conduction in Calcium, Strontium and Barium Zirconates. Solid State Ionics, 61, 65-69. https://doi.org/10.1016/0167-2738(93)90335-Z 